\title{
Derecho Internacional Público
}

\section{EL MANTENIMIENTO DE LA PAZ Y SEGURIDAD AMERICANAS}

\author{
Por el Dr. ROBERT J. HARPER.
}

Cuando se estaba formando la Organización de las Naciones Unidas surgió para los Estados Americanos el problema de como conservar el Sistema Interamericano para la defensa colectiva y la solución pacífica de las disputas y al mismo tiempo promovier y apoyar la nueva organización internacional. A continuación hago un breve resumen de las disposiciones que han sido adoptadas para solucionar este problema, con indicación de como el Sistema Interamericano puede funcionar dentro de las Naciones Unidas en estos asuntos.

La Conferencia Interamericana sobre Problemas de la Guerra y de la Paz, reunida en el castillo de Chapultepec, Méjico, en 1945, adoptó como su resolución VIII la llamada "Acta de Chapultepec" que establece la consulta entre los Estados Americanos en el caso de agresión o preparación para la agresión contra un Estado Americano. Se estipuló que todo atentado de un Estado contra la integridad o la inviolabilidad del territorio o contra la soberania o la independencia política de un Estado Americano, sería considerado como un acto de agresión contra los demás Estados Americanos. Las medidas de defensa connemtiva mu so moden adoptar de acuerdo con esta Acta incluyen la ruptura de las relaciones diplomáticas, consulares, postales, económicas, comerciales y financieras, siendo asi la primera autorización de sanciones por los Estados Americanos. También fué autorizada la aplicación de la fuerza armada para repeler una agresión.

Los Estados Americanos no querían destruir y abandonar su sistema de defensa y seguridad colectiva que habían desarrollado después de tantas confierencias y tanta labor. Por eso consiguieron, de acuerdo con las esperanzas de la Conferencia de Chapultepec, que la Carta de las Naciones Unidas reconociera y contuviera disposiciones para las organizaciones regionales, estableciendo que:

(1) Las partes en una controversia tratarán de buscarle solución, ante todo, mediante la negociación, la investigación, la mediación, la conciliación, el arbitraje, el arreglo judicial, el recurso a organismos $o$ acuerdos regionales $u$ otras medidas pacíficas de su elección. (Art. 33). 
(2) Ninguna disposición en la Carta menoscabará el derecho inmanente de legítima defensa, individual o colectiva, en caso de ataque armado contra un Miembro de las Naciohes Unidas, hasta tanto que el Consejo de Seguridad haya tomado las medidas necesarias para mantener la paz y la seguridad internacionales. (Art. 51).

(3) Ninguna disposición en la Carta se opone a la existencia de acuerdos $u$ organismos regionales cuyo fin sea entender en los asuntos relativos al manteniminto de la paz y la seguridad internacionales y susceptibles de acción regional. El Consejo de Seguridad debe promover tal arreglo de las controversias de carácter local. (Art. 52) Sin embargo, no se aplicarán medidas coercitivas en virtud de acuerdos regionales o por organismos regionales sin autcrización del Consejo de Seguridad. (Art. 53) Se deberá mantener en todo tiempo al Consejo de Seguridad plenamente informado de las medidas emprendidas o proyectadas. (Art. 54).

La Carta de la nueva Organización de los Estados Americanos, adoptada en la Conferencia de Bogotá en abril de 1948, estipula en el Artículo I que "Dentro de las Naciones Unidas, la Organización de los Estados Americanos constituye un organismo-regional". Por tanto, el Artículo 20 de la Carta provee que "Todas las controversias internacionales que surjan entre los Estados Americanos serán sometidas a los procedimientos pacíficos señalađos en esta Carta, antes de ser llevadas a la Asamblea General o al Consejo de Seguridad de las Naciones Unidas". El Artículo 102 dispone que ninguna de las estipulaciones de la Carta se interpretará en sentido de menoscabar los derechos y obli. gaciones de los Estados miembros de acuerdo con la Carta de las Naciones Unidas. De esta manera, la Organización de los Estados Americanos fué integrada con la Organización de las Naciones Unidas y subordinada a ella.

La Carta de la Organización de los Estados Americanos contiene un Capítulo sobre la "Solución Pacífica de Controversias" y otro sobre la "Seguridad Colectiva", pero declara que los medios y procedimientos apropiados deben ser establecidos en tratados especiales acordados entre los Estados Americanos. Con este propósito, fué adoptado en Bogotá el 30" de abril de 1948 el "Tratado Americano de Soluciones Pacíficas" o el "Pacto de Bogotá", habiendo sido firmado anteriormente en Río de Janeiro el "Tratado Interamericano de Asistencia Recíproca".

El Pacto de Bogotá estipula los procedimientos para los buenos oficios, la mediación, la investigación y conciliación, el arreglo judicial y el arbitraje, mientras que el Tratado Interamericano de Asistencia Recíproca incorpora y formaliza los principios de la Declaración de Chapultepec con una importante disposición adicional estableciendo que, en caso de ataque armado contra un Estado Americano, los otros Estados contratantes se comprometen a ayudar a hacer frente al ataque, en ejercicio del derecho inmanente de legítima défensa individual o colectiva que reconoce el Artículo 51 de la Carta de las Naciones Unidas. 
Asi es que el mecanismo interamericano para el mantenimiento de la paz ha sido establecido de tal manera que puede funcionar dentro de las Naciones Unidas. Sin embargo, la Carta de las Naciones Unidas ha establecido que los poderes de esa organización son superiores a los poderes de las organizaciones regionales. Por eso las Naciones Unidas pueden investigar y tomar medidas en un caso americano si deciden no dejar la solución a la Organización de los Estados Americanos. Pero, si la acción de las Naciones Unidas está paralizada por el ejercicio del veto por una de las grandes potencias, entonces parece que la Organización de los Estados Americanos puede funcionar para solucionar el caso. Puesto que los Estados Unidos tienen el derecho del veto en las Naciones Unidas, se ha opinado que ese país puede, cuando lo desee, procurar que el Sistema Interamericano sea independiente de las Naciones Unidas en los asuntos relativos al mantenimiento de la paz y seguridad. 